\title{
Infância e Escola: tempos espaços de crianças
}

\author{
Anabela Rute Kohlmann Ferrarini' \\ Fabiana Rodrigues Oliveira Queiroz' \\ Raquel Gonçalves Salgado'
}

'Universidade Federal de Mato Grosso (UFMT), Rondonópolis/MT - Brasil

RESUMO - Infância e Escola: tempos e espaços de crianças. A infância é abordada, neste artigo, como viés para pôr em discussão o tempo cronológico, demarcado por uma linearidade ordenada pelo progresso e pela racionalidade. Conjugando escritos poéticos de Mario Quintana com os diálogos e os mapas vivenciais das crianças em uma escola, este texto tem como objetivo discutir como tempos e espaços repercutem na construção da infância e nos processos educativos de crianças, no sentido de problematizar as dimensões calculadas e previsíveis que essas categorias assumem nesse contexto social. Buscamos, assim, dar visibilidade ao tempo do inusitado nas experiências das crianças, na escola, ao destacar como, nesse espaço, elas operam rupturas com a temporalidade contínua, progressiva e linear. Palavras-chave: Infância. Tempos. Espaços. Escola.

ABSTRACT - Childhood and School: time and spaces of children. Childhood is analysed, in this article, as an axis to discuss the chronological time, delimited by a linearity ordered by progress and rationality. Combining Mario Quintana's poetic writings with the dialogues and the experiential maps produced by children, the aim of this text is to discuss how time and spaces reverberate in childhood construction and children educational processes, in order to question the calculate and predictable dimensions assumed by these categories in this social context. Therefore, we search to give visibility to the unexpected time in children experiences, in school, by highlighting how, in this space, they operate breaks in the continuous, progressive and linear temporality.

Keywords: Childhood. Time. Spaces. School.

Educação \& Realidade, Porto Alegre, v. 41, n. 4, p. 1027-1048, out./dez. 2016.1027 http://dx.doi.org/10.1590/2175-623660666 


\section{Para Início de Conversa...}

O tempo, como fenômeno que atravessa e conduz a vida humana, tem sido celebrado em verso e prosa há séculos. Também tem sido motivo de angústias, de debates filosóficos, de estudos científicos. Nossas vidas são uma travessia no tempo e no espaço, nem sempre em rota única e programada, mas em trajetos sinuosos e inconstantes, permeada por instantes, memórias, encontros e desencontros. São construídas e reconstruídas na memória, pessoal e coletiva, do tempo que vivemos - e convivemos - e do tempo dos que viveram antes de nós. Sua instituição como um continuum em direção ao progresso engendra mudanças na vida social, como, por exemplo, a datação, que se torna algo importante para a vida cível, inaugurando uma temporalidade cronológica, linear e progressiva, que se apodera da sociedade moderna e passa a ser expressa por números: na história, nas horas, nas idades, nos dias, meses, anos e em todas as instâncias e experiências da vida social.

Tomando a idade como uma das instâncias circunscritas pelo tempo, tratamos, aqui, da infância como categoria social e histórica, fortemente demarcada e instituída por uma temporalidade linear, inscrita na ordem do progresso e da racionalidade, e que a posiciona como um tempo de vida lacunar, aberto a investimentos no presente, com vistas a resultados futuros. Nessa lógica, as crianças, como sujeitos da incompletude, ganham visibilidade como aprendizes de um conjunto de conhecimentos, regras e práticas sociais que os prepara para a vida adulta, tempo consagrado pela plenitude da autonomia, da racionalidade e da produtividade. Todavia, as experiências infantis rompem com essa perspectiva progressista do tempo, prescrita em muitos espaços. Em se tratando de crianças, a escola configura-se como um desses espaços sociais, no qual emergem experiências em que rupturas com o tempo cronos se tornam possíveis. Seu caráter normalizador, que determina o quê, quando e como se deve aprender, contribui para reforçar a visão linear e etapista da vida.

Mario Quintana, com seu olhar poético e sutil, exalta, em sua poesia, o corriqueiro da vida, escrevendo sobre amores e espantos, caminhos e casas velhas, tempo e memória, infância e velhice. Com a ajuda desses quintanares ${ }^{1}$, procuramos refletir sobre crianças e escola, e como tempo e espaço repercutem na construção da infância e no processo educativo, problematizando a sua dimensão mensurável e previsível, que acaba por se apropriar de nossos encontros com o outro e de nossas travessias ao longo da vida, por todos os lugares pelos quais passamos e vivemos.

Como base para as questões que aqui são levantadas e discutidas, trazemos cenários de duas pesquisas, em nível de mestrado, com crianças dos anos iniciais do Ensino Fundamental, que se desenvolveram em momentos distintos, mas na mesma escola da rede estadual de ensino da cidade de Rondonópolis, Mato Grosso. A primeira pesquisa ocorreu

1028 Educação \& Realidade, Porto Alegre, v. 41, n. 4, p. 1027-1048, out./dez. 2016. 
no ano letivo de 2012, em uma turma, com crianças de 8 a 9 anos e uma professora, do terceiro ano do Ensino Fundamental, e a segunda, no ano letivo de 2014, em uma turma do quinto ano dessa mesma etapa da Educação Básica, com crianças de 10 a 11 anos de idade.

Nas pesquisas, são utilizados nomes de personagens da mídia como pseudônimos para identificar as crianças, já que é declarada, nos Termos de Consentimento Livre e Esclarecido (TCLE), a não divulgação de seus nomes, como forma de atender a recomendações do Comitê de Ética da Universidade, na qual as pesquisas se desenvolvem. Nesse caso, as próprias crianças escolhem os nomes de personagens com os quais desejam ser identificadas.

Ambas as pesquisas partem da perspectiva de que a criança é um sujeito com saberes legítimos, e não somente um objeto a ser conhecido, de modo que as relações construídas no processo de pesquisa são atravessadas por esse viés (Jobim e Souza; Castro, 2008). Em vez de pesquisar a criança com o propósito de melhor conhecê-la, passa-se a pesquisar com a criança as experiências socioculturais que ela compartilha com as pessoas de seu convívio. Além disso, as duas pesquisas têm em comum as observações participantes das crianças no cotidiano da escola. Entrevistas e questionários são, também, utilizados como estratégias metodológicas em ambas as pesquisas.

A primeira pesquisa, realizada em 2012, além das crianças, conta com a participação da professora e das mães, posto que seu foco principal é compreender as experiências de crianças e adultos com o universo midiático-tecnológico contemporâneo, assumindo, assim, a perspectiva intergeracional como um importante eixo analítico e metodológico. Por essa razão, as entrevistas e os questionários não se restringem às crianças, sendo trabalhados, também, com a professora e com as mães.

A segunda pesquisa, realizada em 2014, tem como objetivo principal compreender os sentidos que as crianças atribuem aos diversos espaços escolares, as apropriações e reconfigurações que fazem destes a partir de suas relações com as mídias e as novas tecnologias. Nessa perspectiva, os mapas vivenciais se apresentam como a mais importante estratégia metodológica. Esses mapas são procedimentos que conjugam recursos visuais, sob a forma de representações cartográficas, com narrativas. Sua relevância para essa pesquisa reside no fato de revelar elementos do mundo adulto, a partir do que é ofertado às crianças, e os modos como elas significam essas referências (Lopes, 2012). Esse procedimento metodológico visa conhecer as vivências espaciais das crianças no contexto escolar, bem como compreender os seus modos de ser, pensar, estar e agir nesse espaço.

A confecção dos mapas vivenciais, na segunda pesquisa, aconteceu em dias distintos, e se deu no Laboratório de Biologia, espaço concedido pela Coordenação da escola para essa atividade, que se realizou em dois momentos. No primeiro momento, a pesquisadora exibiu para as crianças as fotografias aéreas da escola para que elas pudessem re-

Educação \& Realidade, Porto Alegre, v. 41, n. 4, p. 1027-1048, out./dez. 2016.1029 
conhecer a sua planta baixa e fazer a delimitação do que seria a escola ressignificada por elas. Em seguida, a pesquisadora forneceu às crianças o contorno da planta baixa da escola para que pudessem registrar os espaços ressignificados e delimitados por elas, sob a forma de desenhos (em papel vegetal sobreposto à planta baixa), de acordo com as suas vivências, que foram narradas em grupos de três crianças durante e após a confecção de cada mapa vivencial.

Entretecida com os sentidos dos espaços vividos por crianças na escola está a sensibilidade do poeta Mario Quintana, conjugada às reflexões de autores, como: Agamben (2005), sobre os embates entre khronos e kairos; Elias (1998), sobre o tempo em sua dimensão simbólica; Benjamin (1985), sobre o conceito de história como contrapartida à noção de progresso; Lloret (1998), sobre as idades da vida e como estas participam do processo de constituição identitária; e Arroyo (2008; 2009), sobre a relação entre tempo e escola. Trazemos, também, estudos da Geografia da Infância, ancorados numa perspectiva de infância como categoria social que se transforma nos diferentes espaços que ocupa, os quais, para além de meros arranjos físicos, são lugares dotados de sentidos, que surgem exatamente pelo vínculo que as crianças criam em suas relações de cooperação ou conflito tecidas nessas espacialidades.

\section{Tempo: o átimo e o contínuo}

A ideia - ou, antes, a necessidade - de conceituar o tempo está intimamente ligada à concepção de história e à construção cultural. $\mathrm{O}$ ser humano vive a experiência do tempo e, para representá-lo, utiliza imagens espaciais. Gregos e romanos compreendiam o tempo de forma circular e contínua. Para Aristóteles, o tempo é um continuum pontual, infinito e quantificado, composto de antes e depois, e dividido em instantes que garantem a sua continuidade. "O instante é sempre outro, na medida em que divide o tempo ao infinito, e, contudo, sempre o mesmo, na medida em que une o porvir e o passado" (Agamben, 2005, p. 113, grifo do autor). Essa concepção greco-romana de tempo como um continuum fugidio que nos escapa pelos dedos lança os primeiros fundamentos da noção ocidental quanto à nossa incapacidade de dominar o tempo, o que se torna, paradoxalmente, uma obsessão: de ganhar tempo e de fazê-lo passar conforme a necessidade humana, sempre em direção ao progresso, em uma marcha no interior de um tempo vazio e homogêneo (Benjamin, 1985).

Esse caráter pontual atribuído à história traz a imagem de um passado como arquivo que não pode se ressignificar e que, por essa razão, não dialoga com o tempo de agoras como um momento fecundo de libertação do domínio do sempre igual, no sentido atribuído por Benjamin (1985). Com efeito, salienta Elias (1988, p. 11), “[...] o tempo não se deixa guardar comodamente numa dessas gavetas conceituais”, que atribuem uma forma de experiência comum à humanidade.

1030 Educação \& Realidade, Porto Alegre, v. 41, n. 4, p. 1027-1048, out./dez. 2016. 
É o tempo como eterno duelo entre kairos e khronos, entre o tempo existencial e divino, que se apropria do átimo e do instante, e o tempo quantificado, o tempo humano, delimitado e delimitador. Kairos nos convida a viver o prazer, enquanto khronos nos obriga a postergá-lo. Quintana (2005), conhecedor desse duelo, lamenta que não possamos viver sem outra pretensão que não seja essa mesma: viver. Por isto, nos convoca a colher o instante, em Discreta Alegria (Quintana, 2005, p. 213214), e dele fruir, secretamente, posto que o prazer só pode ser vivido no átimo, na tomada da própria liberdade: "Longe do mundo vão, goza o feliz minuto que arrebataste às horas distraídas. Maior prazer não é roubar um fruto, mas sim ir saboreá-lo às escondidas". Kairos, tempo da descontinuidade, do prazer e do instante, opõe-se ao controle e à previsibilidade do tempo cronológico do relógio, do calendário e da história.

A supremacia do pensamento clássico perdura até o início da era cristã, que faz surgir a representação do tempo como uma linha reta, com princípio, meio e fim. A narrativa do Gênese é o marco inicial do universo criado por Deus, enquanto o Apocalipse é seu destino final e inescapável. De um extremo a outro, a humanidade passa por um processo de redenção e cura, centralizado na ressurreição de Cristo, no percurso progressivo empreendido em direção a Deus. O tempo, no Cristianismo, se aparta do natural movimento celeste para tornar-se um “[...] fenômeno essencialmente humano e interior" (Agamben, 2005, p. 115). Para Santo Agostinho, é no próprio espírito que mensuramos o tempo. No poema Da Morte, Quintana se diverte com a certeza de sua própria finitude, aprendida entre orações, imagens de anjos e santos e outras lições cristãs, comuns a algumas infâncias: "Um dia... Pronto! Me acabo. Pois seja o que tem de ser. Morrer, que me importa? O diabo é deixar de viver" (Quintana, 2005, p. 231).

Na modernidade, encontramos o antes e o depois, conceitos que forjam uma noção de tempo histórico entendido como processo, contrária à noção do tempo cristão, retilíneo e irreversível. No processo de sucessão temporal, o presente só tem sentido quando se coloca entre o ontem e o amanhã, quando se revela pelo que aconteceu antes e pela prospecção do que virá depois.

Com Benjamin (1985, p. 225), deparamo-nos com uma perspectiva de história bem distinta do tempo de sucessões, uma vez que passado, presente e futuro se entrecruzam, diluindo qualquer perspectiva de linearidade. Para ele, a rememoração do passado não significa a recuperação do que de fato ocorreu, mas sim a busca de sentidos outros a partir das ruínas deixadas para trás e das vozes sufocadas em meio aos acontecimentos históricos. Trata-se de "[...] escovar a história a contrapelo" ao buscar no passado os rastros devastados pelos bens culturais herdados pelos vencedores e assumir uma atitude crítica perante o presente e o futuro, expressa na construção de experiências que se desviem do fluxo da história, ditado pelo progresso, e tenham como suporte as marcas deixadas por essa devastação. 
Infância e Escola

Há um quadro de Klee que se chama Angelus Novus. Representa um anjo que parece querer afastar-se de algo que ele encara fixamente. Seus olhos estão escancarados, sua boca dilatada, suas asas abertas. O anjo da história deve ter esse aspecto. Seu rosto está dirigido para o passado. Onde nós vemos uma cadeia de acontecimentos, ele vê uma catástrofe única, que acumula incansavelmente ruína sobre ruína e as dispersa a nossos pés (Benjamin, 1985, p. 226, grifo do autor).

Tal concepção de história traz como pressuposto a crítica à noção de progresso como norma histórica, que traça uma trajetória cuja meta é a perfeição infinita. Ao romper com a marcha imposta pelo progresso, que faz da história um tempo homogêneo, o autor se recusa a ver o passado como guardião de acontecimentos absolutos e o presente como preparação para um futuro do qual se espera muito mais certezas do que novidades. A crítica do progresso como motor dos acontecimentos, aponta Benjamin, é a crítica do tempo linear e a construção de uma experiência que toma o presente não mais como transição entre passado e futuro, mas como lugar onde a história é pensada e ganha outros sentidos provocados por desvios e rupturas que desmancham os elos da cadeia dos fatos históricos.

Para orientar-se no tempo, o homem criou instrumentos que pudessem mensurá-lo: os relógios e os calendários. Os relógios cumprem as mesmas funções dos fenômenos naturais, como o ciclo da lua no céu, o pulsar do próprio coração, a aurora e o poente que se repetem dia após dia: guiar a humanidade na sucessão e ordenação de processos sociais e físicos. Esses fenômenos serviram como forma de "[...] harmonizar as atividades dos homens e adaptá-las a processos que lhes eram externos, da mesma maneira que foram adaptadas, em estágios posteriores, aos símbolos que se repetem no mostrador de nossos relógios" (Elias, 1998, p. 8). Os calendários representam a sequência irreversível de meses e anos, que se sucedem numa continuidade móvel, natural e social: estruturas recorrentes de um devir que não volta jamais.

Relógios e calendários são temas muito cantados pelo poeta Quintana, a quem tanto apraz o cotidiano. Num de seus versos, ele define o tempo como “[...] um ponto de vista dos relógios" (Quintana, 2005, p. 357). Talvez seja isso mesmo: nós olhamos o relógio e ele nos responde no seu monótono repetir de segundos, minutos e horas, em que tempo estamos - e somos. Os ponteiros do relógio nos indicam a posição que ocupamos na amplidão do devir, assim como podem indicar o tempo necessário para nos deslocarmos de um lugar a outro: são objetos feitos pelas mãos e pelo engenho do homem para nos transmitir mensagens sobre o tempo. Para o poeta, “[...] não se devia permitir nos relógios de parede esses ponteiros que marcam os segundos: eles nos envelhecem muito mais que o ponteiro das horas” (Quintana, 2005, p. 330).

O relógio e o calendário são representações do tempo khronos a nos controlar, implacável, em seu percurso natural conjugado a uma 
realidade social. Mas o tempo não é o humano $e$ a natureza. O tempo é o humano na natureza, transformando-a, produzindo cultura. Assim, a experiência do tempo é aprendida no convívio social. Enquanto cresce, a criança sofre uma espécie de coerção social, disciplinadora, que lhe ensina o habitus social, inserindo-a no processo civilizatório. Essa coerção se transforma em autodisciplina, em capacidade de integrar uma comunidade humana e "[...] interpretar os sinais temporais usados em sua sociedade e a orientar sua conduta em função deles" (Elias, 1998, p. 15).

\section{Os Tempos de Vida na Cultura: as idades, os encontros, os desencontros e confrontos}

Eis que descubro um retrato meu, aos 10 anos. Escondo, súbito, o retrato.

Sei lá o que estará pensando de mim aquele guri!

(Quintana, 2005, p. 310)

A perplexidade do envelhecido Quintana, diante do menino Mario, que o encara de dentro do retrato, expressa as mudanças do mundo, da sociedade e de si mesmo. Expressa, igualmente, as mudanças nas relações entre adultos e crianças, tão relevantes que causam ao velho um temor de ser julgado pelo guri. Na perspectiva da sociologia da infância, a criança, assim como o adulto, é definida como um sujeito que se constitui na história e na cultura e, simultaneamente, também produz culturas.

Desde o dia em que nascemos e abrimos nossos olhos para o mundo, enquanto crescemos, o tempo é ensinado e aprendido. Assim como aprendemos sobre o tempo como eventos que ordenam nossas vidas, como canta Quintana (2005, p. 138), em Canção de Junto do Berço, “[...] não te movas (diz-lhe a Noite), que inda está cantando um grilo... Abre os teus olhinhos de ouro (o Dia lhe diz baixinho)... é tempo de levantares, que já canta um passarinho...", também aprendemos sobre os tempos que definem nossas vidas. Como aponta Corsaro (2011, p. 32), “[...] as crianças estão, por sua própria participação na sociedade, restritas pela estrutura social existente e pela reprodução social, ou seja, a criança e sua infância são afetadas pelas sociedades e culturas que integram".

Aprendemos que, além de sermos homens ou mulheres, meninos ou meninas, jovens ou velhos, de termos um nome, palavra que nos identifica, somos e pertencemos a uma determinada idade, que não é somente nossa, é também do outro que, assim como nós, é e pertence a uma idade. Ser uma mulher de 30 anos ou uma criança de cinco anos - afirmação a partir da qual Lloret (1998, p. 14) põe em discussão a preposição $d e$, nada fortuita ou ingênua, dado o seu sentido de indicar que somos propriedade de alguns anos e que, sendo assim, seguimos, ao longo da vida, sendo inscritos a grupos determinados de idade: "mais do que ter uma idade, pertencemos a uma idade. Os anos nos têm e nos

Educação \& Realidade, Porto Alegre, v. 41, n. 4, p. 1027-1048, out./dez. 2016.1033 
fazem; fazem com que sejamos crianças, jovens, adultos ou velhos". Situados nesses grupos etários, somos compelidos a determinados comportamentos e práticas sociais que definem o ser de uma idade. Assim, nosso tempo se torna prisioneiro das convenções que o outro nos impõe, normalizadas e socialmente pertinentes, pois os discursos sobre ser de determinada idade se corporificam subjetivamente e participam ativamente de nossa constituição identitária ao fazer-nos e refazer-nos. Há idades para tudo: idade para frequentar a escola, idade para trabalhar, idade para amar, idade para ser pai ou mãe. A idade se constitui, portanto, como um forte elemento homogeneizador.

Moriyón (2010) lembra-nos que o processo de desenvolvimento humano é marcado pela continuidade: cada indivíduo possui uma biografia segmentada por diferentes momentos e etapas unificados em uma história pessoal, dotada de coerência e sentido. Amparado pela ciência positivista, o discurso do desenvolvimento humano carrega uma concepção de vida compartimentada em etapas, que definem o crescimento e a maturação. Afirma-se, assim, o caráter universal e linear da trajetória da existência humana, diluindo sua história social e cultural. Nessa lógica, o desenvolvimento humano deve percorrer uma linha reta que se consagra como norma, cujo início marca o germe do autocontrole e da adaptação social, metas que se aperfeiçoam gradativamente no decorrer da vida humana (Castro, 1999).

Porém, assim como existe a normalidade, há o desvio. Nos dias atuais, tem se tornado cada vez mais comum encontrarmos pessoas que não se situam no interior dos enquadres desenhados pelos anos de vida. Aumentar ou reduzir a idade é quase um gesto de rebeldia, como se o sujeito reclamasse para si o direito de não ser julgado - de viver, enfim - por um atributo cronológico. Quintana brinca sobre sua condição de velho ante a criança que ele mesmo foi e as crianças de hoje, dizendo: "Quando guri, eu tinha de me calar, à mesa: só as pessoas grandes falavam. Agora, depois de adulto, tenho de ficar calado para as crianças falarem" (Quintana, 2005, p. 282). O poeta expressa a mudança do mundo, da sociedade e de si mesmo. Em outro momento, nos faz lembrar quando, durante a infância, ansiávamos por ser crescidos e sérios, imitando o comportamento dos adultos e, quando adultos, tentando nos desviar do que é normal para esse grupo, agimos ou fazemos coisas inadequadas ou dignas de reprovação: "- Mas por que você não escreve umas coisas mais sérias? - Ora, tia Élida! Eu já não sou mais criança...” (Quintana, 2005, p. 781).

\section{Para Sarmento (2011),}

[...] as formas de ser e de agir das crianças contaminam, alteram, modificam permanentemente as práticas familiares, escolares, institucionais, e dos territórios e espaços sociais em que se encontram. Apesar de isso ser normalmente ignorado, a verdade é que as crianças agem e a sua acção transforma os lugares em que (con)vivem com os

1034 Educação \& Realidade, Porto Alegre, v. 41, n. 4, p. 1027-1048, out./dez. 2016. 
adultos. As micro-transformações que ocorrem, por efeito de agregação e de interdependência dos contextos de existência têm influência sobre o conjunto da sociedade (Sarmento, 2011, p. 585, grifo do autor).

Existe a possibilidade, afirma Lloret (1998), de construir uma identidade flexível e diversificada, desenhada pelas experiências que vivemos, uma vez que uma idade não exclui a outra, mas a contém. “Triste de quem não conserva nenhum vestígio da infância...” (Quintana, 2005, p. 825). A memória permite que façamos uma incursão em outros tempos de nossa própria vida. Trazemos em nós a criança e o jovem que fomos, que vivenciou amores, prazeres e dores, sucessos e fracassos, sonhos e realizações, tempos que nos moldaram e nos fazem ser como somos. Se olharmos para o futuro, a pessoa que hoje somos e a que fomos estarão lá, presentes na pessoa que seremos.

Lloret (1998) compreende a idade não apenas como uma atribuição cronológica, mas como um elemento determinante das expectativas de relação e de comportamentos. As idades se organizam segundo as identidades "outorgadas na família, na escola, no trabalho e em outros lugares de convivência, a partir de possibilidades de relação [...] de aceitações e rejeições, de hierarquias e sentimentos para com os demais e para consigo mesmo" (Lloret, 1998, p. 21-22). Nesses diferentes ambientes sociais, cada idade tem diferentes papéis a desempenhar, papéis esses que, conforme a idade que alcançamos, podemos desejar representar.

Sem dúvida, no mundo contemporâneo, as fronteiras entre as idades e, por sua vez, entre os tempos de vida, tornam-se instáveis, haja vista que os papéis convencionais atribuídos aos adultos e às crianças vão perdendo sua fixidez, ganhando mais plasticidade. Se outrora a criança era vista como um ser marcado exclusivamente pela inocência e fragilidade, cujo desenvolvimento dependia estritamente do controle adulto, por meio de uma educação pautada na disciplina e moralização, hoje ela assume o lugar de protagonista, um dos alvos privilegiados da sociedade de consumo. Se outrora a família e a escola eram instituições basilares para a socialização e a educação das crianças, hoje elas contam com o aporte das mídias eletrônicas, com a quais têm mantido estreitas relações, que se traduzem em outros conhecimentos e experiências, que fazem parte de seus processos de subjetivação.

São cada vez mais comuns os ambientes sociais em que o comportamento, a linguagem, as atitudes, os desejos, e até mesmo a aparência física de adultos e crianças, estão em aproximação. Idades que se tocam, fronteiras etárias que se desfazem, e refazem mapas das temporalidades humanas que se redesenham. Acontecimentos estes que afligem nosso tempo contemporâneo, trazendo perguntas, dúvidas, angústias e possibilidades de aprendizagens. Buckingham (2000), avesso à morte da infância, anunciada por Postman (1999), em função da emergência de experiências muito próximas às do mundo adulto, que

Educação \& Realidade, Porto Alegre, v. 41, n. 4, p. 1027-1048, out./dez. 2016.1035 
passam a ser compartilhadas por crianças e contam com os aportes da mídia, a partir da segunda metade do século XX, argumenta que fronteiras entre infância e vida adulta são desenhadas e redesenhadas, ao passo que as referências simbólicas em que estas se constituem também vão assumindo novas facetas.

Esses encontros podem significar uma “[...] possível inadequação provocada pela imagem dos anos: um calendário que quase sempre nos torna muito pequenas ou pequenos, demasiado velhas e velhos, por demais jovens" (Lloret, 1998, p. 23). Vivemos cerceados por expectativas vinculadas aos nossos anos de vida e projetadas para o futuro, em especial quando nos referimos às crianças em alteridade com os adultos. Nosso ideário projeta sobre elas determinados comportamentos e linguagens que entram em confronto com a infância concreta que aí está, transitando entre o que se espera de um adulto ou de uma criança. No poema O Velho do Espelho, Quintana (2005) se surpreende com sua própria velhice, que o torna tão semelhante ao pai, ao mesmo tempo em que se põe no papel do filho criança/jovem que desafia e frustra os planos paternos:

Eu, Pai?! Tu é que me invadiste,

Lentamente, ruga a ruga... Que importa? Eu sou, ainda, Aquele mesmo menino teimoso de sempre

E os teus planos enfim lá se foram por terra.

Mas sei que vi, um dia - a longa, a inútil guerra! -

Vi sorrir, nesses cansados olhos, um orgulho triste...

(Quintana, 2005, p. 410)

Esses confrontos intergeracionais sempre existiram e, na contemporaneidade, têm se mostrado ainda mais intensamente, atravessados que são pelos discursos da mídia, pelo convívio com as tecnologias e pelo consumo, partícipes inegáveis das vidas de crianças e adultos. A infância de hoje vive sob o signo da ambivalência: atribuímos a ela um papel de protagonista na história, bem como a reconhecemos como um tempo de vida com características próprias que devem ser respeitadas e, no entanto, lhe negamos esse protagonismo, pois não é permitido às crianças participar da condução de suas vidas. Ao mesmo tempo, as instituições sociais, como a família e a escola, se mantêm apegadas a conceitos de infância cristalizados e naturalizados ao longo da história (Moriyón, 2010).

\title{
Notas sobre o Tempo e suas Implicações na Infância
}

\author{
A vida é uns deveres que nós trouxemos para fazer em \\ casa. \\ Quando se vê, já são 6 horas: há tempo... \\ Quando se vê, já é 6a feira... \\ Quando se vê, passaram 60 anos... \\ Agora, é tarde demais para ser reprovado...
}

1036 Educação \& Realidade, Porto Alegre, v. 41, n. 4, p. 1027-1048, out./dez. 2016. 


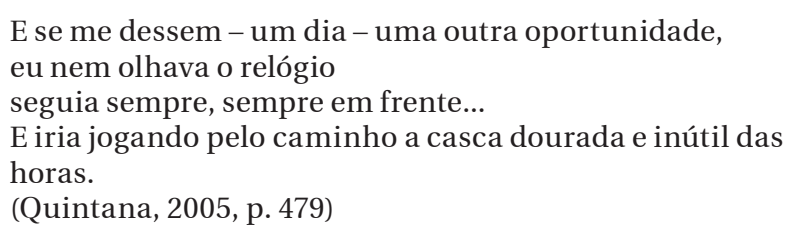

Nos versos de Quintana, a vida se assemelha à escola: são deveres, horários e cronogramas a cumprir, enquanto o tempo passa, inexorável, a nortear as experiências humanas. Dentre as instituições sociais existentes, a escola está intimamente ligada à ideia de tempo como progresso. A escola se organiza em função do tempo: a gestão se preocupa com o tempo delimitado para cumprir as obrigações junto ao Estado. Os professores se preocupam com o tempo para dar cabo dos conteúdos instituídos e programados. Os estudantes correm contra o tempo, pressionados pelas aferições internas e externas da aprendizagem no tempo pré-determinado como marca da exatidão do aprender. Existe uma lógica temporal que prescreve os tempos para a aquisição da escrita, do cálculo, da leitura, e os programas escolares seguem essa lógica, fragmentando-os segundo uma sequência preestabelecida. Tanto a formação quanto as aprendizagens e as relações entre os estudantes vinculam-se a esse tempo sequencial, assim como os educadores são obrigados a cumpri-lo (Arroyo, 2009).

A história social desafia a pedagogia a perceber a dinâmica da sociedade, em que as imagens da infância se constroem e desconstroem, e, assim, reconhecer as experiências constituintes da infância, ou seja, para além de ver crianças e adolescentes como sujeitos que empreendem percursos individuais de aprendizagem, é preciso vê-los como membros de uma categoria social e geracional, que se coloca em alteridades múltiplas com outras gerações. Nesses encontros, salienta Arroyo (2008), crianças e adolescentes aprendem e constituem saberes, comportamentos, valores, culturas e identidades.

Lopes (2009) afirma que a perspectiva da negatividade é um traço que tem acompanhado a infância: o próprio termo infância, do latim in-fans, significa aquele que não fala, e essa concepção se perpetuou, em outros momentos históricos, como a idade da não razão e do não trabalho.

Ressaltamos aqui como a idade assume papel determinante no tempo da vida social. Conforme destaca Lloret (1998), há uma imagem reducionista que precede e que segue a idade adulta, com os atributos de carência, ganho e perda, o que confere tanto à infância quanto à velhice uma posição de desvantagem em relação à vida adulta. Para a autora, as idades assumem tantos significados quantas forem as identidades requeridas nos diferentes espaços sociais em que se vive, como a família, a escola e o trabalho. Ao lado da família, a escola tem desempenhado papel determinante na preparação das crianças para o futuro. Seu formato regulador se apoia na ideia de uma linha temporal retilínea rumo ao progresso.

Educação \& Realidade, Porto Alegre, v. 41, n. 4, p. 1027-1048, out./dez. 2016.1037 
Infância e Escola

Nesse contexto, a escola, como um dos pilares do sistema capitalista moderno, assume o papel de civilizar os indivíduos que nela se inserem. Todavia, em muitas situações, as experiências das crianças rompem com a perspectiva progressista do tempo pontual. Isto se torna perceptível em suas expressões, linguagem e ações. O diálogo das crianças com o tempo parece seguir outra lógica, que não a cronológica, como se houvesse um acordo entre elas e o tempo, que as lança para fora do círculo da previsibilidade e do sempre eterno, em diversos contextos espaciais, inclusive o escolar.

Nessa perspectiva, o tempo, que parece ser contínuo, é rompido, e o caráter normativo da escola é minado pelas experiências do tempo kairos. Esse fato nos faz refletir sobre os atravessamentos do tempo, não mais pela rota do previsível, nas experiências vivenciadas no espaço escolar, problematizando o caráter regulador dessa instituição socialmente constituída.

\section{Escola: espaço de tensões entre o tempo produtivo e o tempo livre}

O tempo livre, ou ócio, se constitui em tempo e espaço para a formação humana, por isso, trazemos esse conceito para refletirmos sobre as possibilidades de sua presença no contexto escolar. Aproximar os temas do ócio, da infância e da educação traz à discussão um princípio educativo básico que predomina em nossas escolas, isto é, a educação entendida como trabalho. Para Vasconcellos (2009, p. 83-84), existe “[...] um jogo de forças no qual o tema do brincar se insere, a saber, as relações entre lazer/trabalho, dever/prazer - e entre estes - a questão do ócio". A reflexão sobre o ócio, afirma a autora, é antiga e acompanha a história. O ócio, para Sêneca, era fundamental para regenerar as forças, impulsionar o novo e dar alento ao espírito, cultivar o conhecimento e a virtude, enfim, caracteriza-se como um "tempo livre", para ocupar-se da própria existência, da amizade e do bem comum.

Lafargue (2003), em seu manifesto O direito à preguiça (1883), sinaliza que o proletariado submeteu-se ao dogma do trabalho, afastando-se do convívio com os amigos e com a família, em detrimento da valorização do descanso, da diversão e do recolhimento. O ócio transformou-se, então, em vadiagem, em inútil desperdício de tempo que segue na contramão da ânsia pela produção incessante de riqueza.

Dessa lógica, nem mesmo a escola escapa, visto ser lugar de produção cujo tempo é o do aprendizado. A criança, sob essa óptica, é vista, fundamentalmente, como aluno, aprendiz, repositório dos saberes que a escola lhe fornece. Quando perguntadas sobre o que as diferencia dos adultos, as crianças reverberam esse pensamento: primeiro, porque estar na escola significa estudar, entendido, aqui, como o trabalho das crianças, como diz Salsicha ${ }^{2}$, em conversa com a pesquisadora. Já para a menina Alex, brincar e estudar formam o binômio da infância, en-

1038 Educação \& Realidade, Porto Alegre, v. 41, n. 4, p. 1027-1048, out./dez. 2016. 
quanto, para os adultos, resta trabalhar, trabalhar e... trabalhar! [...] pra ser alguém na vida! Essa compreensão de vida adulta se estende a eles próprios, quando falam de seu futuro e da infância: a infância é o tempo da liberdade, e a vida adulta, o das obrigações. Para muitos, as crianças são “[...] pessoas descarregadas de deveres e carregadas de direitos, às quais em nenhum caso se deixa participar ativamente na sociedade, a não ser como consumidor de bens" (Moriyón, 2010, p. 150). Este aspecto satura a infância na lógica capitalista do trabalho e do consumo, inclusive o tempo do brincar, que se esvai nesse modelo de vida, e desnuda a perda do tempo do ócio nas experiências das crianças, inclusive naquelas que se constroem na escola. São muitas as tarefas e exigências impostas às crianças, assim como é demarcado e cronometrado o tempo para que cada uma delas seja cumprida. Nesse esquadrinhamento do tempo e do espaço na escola, não sobram brechas para experiências diversas e para a própria experiência de aprender. Mas as crianças, de alguma forma, desprendem-se desses limites e

\begin{abstract}
[...] encontram rotas de fuga. Brechas para um tempo de pausa. Para a vivência amorosa e preguiçosa do prazer de descobrir a si e ao mundo. Não é um tempo de ação. É um tempo de atenção. Mas não a atenção focada do pensamento ou da racionalidade. E sim uma atenção difusa, aberta, à espera ou à espreita não se sabe bem de quê. É uma atenção ao que está fora, mas também ao que está dentro. [...] E, nesse sentido, contemplar é também contemplar-se (Vasconcellos, 2009, p. 90).
\end{abstract}

Desse modo, somos provocados pela infância a repensar os espaços e tempos da escola. A escuta sensível das vozes infantis pode indicar formas e caminhos de se construir uma escola que valorize o tempo da infância não só como tempo de ler, escrever e fazer contas, mas como tempo de outras experiências e convivências, pequenas ou grandes, que acontecem não só no espaço/tempo da sala de aula, mas nos corredores, nos pátios, nos esconderijos, no recreio, nas brincadeiras, nas conversas segredadas ao ouvido dos pares, ora amigos e amigas, cúmplices, ora adversários, mas sempre interlocutores nessa trajetória e jornada.

\title{
Espaços e Tempos de Escola: o que dizem as crianças
}

Nas reflexões que temos realizado até aqui, problematizamos o tempo como fenômeno que interpela a vida, em particular, a das crianças, que o ressignificam por meio de suas linguagens e sentidos, assim como constroem relações e experiências com os espaços que ocupam. Mas por que realizarmos o entrelaçamento entre os conceitos tempo e espaço? A resposta está no fato de que as experiências que nos tocam emergem de nossas relações com o outro e são vividas tanto no tempo quanto no espaço, seja ele real, como as salas de aula, o pátio, a praça, ou virtual, uma vez que, no mundo contemporâneo, os encontros com o outro se dão, também, nos espaços virtuais. 
Tempo e espaço são dimensões que se interpenetram e, nesse entrelaçamento, produzem sentidos, culturas e histórias. Bakhtin (1992), com o conceito de cronotopo, assinala a possibilidade de vermos e lermos o tempo no espaço, postura que o preenche e nos coloca diante de um acontecimento. Nesse movimento, deparamo-nos com o tempo histórico, possível apenas com as marcas da atividade criadora e aquelas impressas pela mão e espírito humanos. É nesse tempo que as inscrições temporais no espaço ganham visibilidade e se consagra "[...] a união indissolúvel do tempo do acontecimento ao lugar concreto de sua realização" (Bakhtin, 1992, p. 262). Eis aí uma das marcas fundantes da cultura, como necessidade humana que penetra o tempo e vincula-o ao espaço. O cronotopo, para Bakhtin (1992), remete ao todo indissociável formado pelo entrelaçamento do tempo com o espaço. Por esse viés, o espaço já não mais é contemplado como uma paisagem abstrata e o acontecimento já não pode ser tomado como o fragmento de um tempo indeterminado. O espaço é, portanto, parte irremovível do mundo, de um mundo que é constitutivo da história humana. Da mesma forma, o acontecimento é irremovível do tempo da história, de uma história que apenas se realiza no mundo.

As vivências do espaço escolar não fogem a isso. São espaços, marcados por histórias, códigos, regras, hierarquias, valores e perspectivas sociais, que fazem com que as paisagens escolares não sejam esvaziadas de sentidos. Desse modo, esses espaços são marcados por acontecimentos que os significam por estarem imersos numa história que se encarna nas paisagens do cotidiano escolar. Como forma de evidenciar os tempos e os espaços que marcam a vida escolar de muitos educandos, recorremos aos estudos realizados por Andrade e Teibel (2012) acerca dos discursos das crianças sobre a escola e suas representações desse espaço-tempo, nos quais fica claro que, como instituição educativa, a escola apresenta alguns reguladores sociais que dizem o que se pode ou não fazer e os lugares a que se deve ou não ir, tendo o sino, por exemplo, como um forte regulador, que "[...] aparece associado a situações que configuram um script, cronologicamente construído: recreio, beber água e ir ao banheiro" (Andrade; Teibel, 2012, p. 133).

No exercício de refletir sobre o espaço da escola, no contexto da segunda pesquisa, as crianças produziram narrativas e mapas vivenciais, confeccionados a partir de uma releitura da escola durante a pesquisa de campo. Tanto no mapa desenhado pelos meninos Mice e But (Figura 1), como no que é por eles dito, inscreve-se uma perspectiva diferente daquela usualmente conferida à escola, o que nos convida à reflexão. 
Figura 1 - Mapa de Mice e But

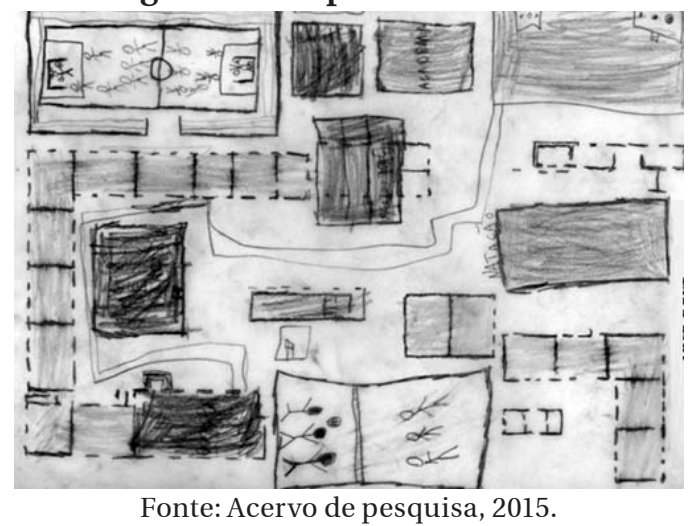

Mice: E o que que nós podemos fazer mais nessa escola, cara? Ah!... Uma academia!

But: Academia! Olha o outro![risos]

Pesquisadora: Por que uma academia, Mice?

Mice: Para ficar bombado!

A escola, na perspectiva das crianças, aparece como espaço para compartilhar o dia, realizar atividades culturais e esportivas, desconstruindo sua visão como espaço exclusivo para o estudo. Interessante perceber, aqui, o valor que a escola tem, para elas, como espaço coletivo em que podem compartilhar e produzir culturas: estar junto com outras crianças. Como apontam Venn e Vrakking (2009), a escola é apenas uma parte da vida das crianças, sabedoras como são da necessidade e da importância de frequentá-la, entretanto, parece ser por elas percebida mais como um espaço social para construir amizades e para o convívio com seus pares do que para fins estritamente cognitivos.

Para além de dar forma à sua escola ideal, Mice e But planejam aulas mais atraentes, que se distanciem do tradicional funcionamento e organização da escola e do ensino. Nesse sentido, propõem aulas que têm aspectos mais próximos de diversão, como as de natação e dança, intercaladas com as matérias curriculares, tal como as conhecemos.

Mice: Eu queria ter meia hora de recreio.

But: Meia hora não! Uma hora!

Mice: Não, meia hora! Eu queria estudar até nove horas da noite.

Pesquisadora: É!?

Mice: Ia ser legal, ia ter: lugar de dança, natação, academia, biblioteca, jogar bola... eu ia precisar da uma hora até as nove.

But: Mas eu não queria ficar estudando toda hora, não...

Mice: Eu queria um dia só para... Tipo assim: um dia só pra passar uma matéria, outro dia só para outra matéria e um dia só para brincar no lugar de dança, biblioteca, academia e natação, e um dia só para todas as matérias, entendeu? 
Longe do cenário regulador, os espaços e tempos desejados estão, geralmente, relacionados ao contexto fora da sala de aula, no qual se travam relações de poder pela ocupação dos espaços permitidos e dos nãos permitidos, subvertendo a existência de normas e regras pré-estabelecidas, como se observa tanto no mapa vivencial quanto nas declarações de Mice e But, em que ficam nítidos os significados e a atração que a quadra de esportes tem para as crianças. Isso se evidencia na confecção e releitura dos espaços da escola, já que as crianças registram sua presença exclusivamente na quadra, compreendida e sentida como vivência de prazer, o que é percebido, também, em outras espacialidades por elas inseridas em seus mapas, como o pátio e a biblioteca.

Há que se ressaltar que, não obstante todas as mudanças pelas quais o mundo passa, sobretudo no que tange à revolução midiática e comunicacional e ao impacto que isso representa na vida das pessoas, o universo educativo pouco se modifica, mantendo vivo o caráter regulador, que aprisiona o tempo e cerceia múltiplas vivências dos espaços escolares.

Ainda assim, as crianças, em seu ofício de viver a infância,

[...] subvertem cotidianamente a lógica de produção da escola centrada na idolatria do trabalho e da competitividade e criam nichos de ócio: brincam. Desocupadas de produzir produzem-se: na brincadeira entre seus pares, na relação contemplativa de si e do mundo, na atenção prioritária às desimportâncias, às coisicas, na preguiça de quem brinca com o tempo insubmisso (Vasconcellos, 2009, p. 87-88).

Os espaços reguladores, tais como as salas da coordenação e direção, são, ainda, os menos apreciados pelas crianças, que buscam rotas alternativas para deles fugir, à procura de espaços e tempos investidos de prazer e sentidos. No mapa produzido por Pinkie Pie, Fluttershy e Ana Louise (Figura 2), esse anseio torna-se evidente.

Figura 2 - Mapa de Pinkie Pie, Fluttershy e Ana Louise

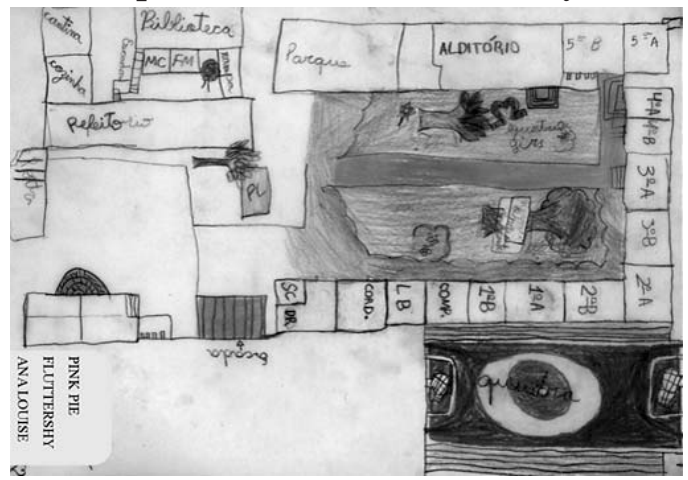

Fonte: Acervo de pesquisa, 2015.

1042 Educação \& Realidade, Porto Alegre, v. 41, n. 4, p. 1027-1048, out./dez. 2016. 
As meninas demarcam os lugares que consideram legais com grande riqueza de detalhes: a quadra, o pátio e a sala de aula. A coordenação e a diretoria são reputadas como lugares chatos. A gruta, quase ao centro do pátio, abriga uma imagem católica e oferece livre acesso, sendo vista como parte integrante da escola, usualmente frequentada pelas crianças para a prática de brincadeiras. Em seu desenho, elas imprimem cor à quadra, dando-lhe destaque entre os espaços preferidos, capaz de proporcionar-lhes experiências significativas e a fuga da regulação presente em outros espaços. Além da quadra, é notória a atenção dada às áreas verdes da escola, cheias de cor e beleza, que se contrapõem à representação de outros espaços, que indicam o aspecto austero e disciplinador neles demarcado.

Desse modo, é possível compreender que não apenas o sino, destacado por Andrade e Teibel (2012), mas outros reguladores se fazem presentes no cotidiano escolar das crianças, fato este que nos leva a compreender que o estar fora da sala da aula ou a subversão às regras instituídas na escola estão associados ao não reconhecimento pelos direitos das crianças de participarem na gestão daqueles espaços e tempos nos quais estão diretamente implicadas. As escolas, embora sejam espaços nos quais as crianças passam significativa parcela de suas vidas, não são, em sua maioria, instituições planejadas para recebê-las. Há, nas crianças, o anseio por uma escola de fato sua, convidativa, participativa e alegre, não tediosa, limitadora e triste.

Versa Quintana (2005, p. 182): "De cada lado da sala de aula, pelas janelas altas, o azul convida os meninos, as nuvens desenrolam-se, lentas, como quem vai inventando preguiçosamente uma história sem fim... Sem fim é a aula: e nada acontece, nada. Bocejos e moscas". Em se tratando de escola, aflige-nos afirmar ser esta uma reflexão atemporal, posto que, mesmo nos dias de hoje, no interior das escolas, as crianças podem sentir-se desconectadas do espaço da sala de aula e, na relação com o professor, podem ignorar ou desinteressar-se pelas explicações sobre o mundo e a vida, dada a monotonia que se apodera tanto do espaço quanto da relação. Ao manter formas arcaicas de organização e ensino, pensadas segundo uma noção tradicional de infância, a escola se afasta dos contextos de vida em que nos encontramos hoje, adultos e crianças, com celulares e computadores que se constituem como janelas escancaradas para o conhecimento do mundo. Se o mundo está mudando aceleradamente - tanto nos processos de comunicação como nas configurações culturais -, é certo que são muitos os desafios postos a quem trabalha e convive com crianças e adolescentes.

A professora, participante de uma das pesquisas e responsável por uma das turmas de crianças, percebe, na escola, um cenário no qual muitos professores resistem e, até mesmo, se negam a utilizar qualquer inovação. Ela própria sugere que os professores sejam preparados para atuar com as novas tecnologias, aproveitando, para isso, momentos da formação: “[...] tem gente que não consegue mexer, lidar com isso. Por 
que não usar o tempo de formação que a gente tem na terça-feira, que a gente fica só falando, falando, porque não dar uma formação de aprender a mexer com esses meios?".

Diante dessa postura adulta, resta às crianças tentativas de burlar o controle, utilizando espaços, como o banheiro, para acessar, às escondidas, as redes sociais, especialmente para fazer selfies no espelho e enviar aos amigos. O banheiro, como espaço para o uso das tecnologias interditadas pela ordem institucional, representa, no âmbito da escola, o espaço da privacidade, do segredo e, portanto, das resistências. Nas relações com as tecnologias digitais, as crianças estabelecem novas sociabilidades, que se instauram a partir de um outro que se virtualiza, mas, ainda assim, se apresenta como instância importante para a relação de alteridade estabelecida para a composição da imagem de si. O ato de tirar a foto, portanto, emerge com uma finalidade específica que se volta para o outro e, consequentemente, para o auditório social que esse outro representa ao receber a sua imagem. $\mathrm{O}$ uso das tecnologias, sobretudo no espaço da sala de aula, aparece como uma das mais visíveis e significativas subversões às regras institucionais exercidas pelas crianças.

Desse modo, ponderamos que, quando o processo ensino-aprendizagem se faz significativo para a vivência das crianças, ele produz prazer e mobiliza transformações subjetivas, mas a rotina pautada e orientada pela lógica tradicional afasta o prazer e o desejo pelo conhecimento, assim como pelos lugares e tempos que representam o controle e a preparação para um futuro.

\section{Inconclusões}

O tempo nos intriga e confunde. Vivemos nele e ele vive em nós. Desde o berço, recebemos lições sobre a passagem do tempo, sobre a organização social e cultural da vida, sobre a trajetória humana - individual e coletiva - e sobre nossos tempos de vida. O exercício e as marcas do tempo também se imprimem no espaço, compondo ambos um todo indissolúvel, afirma Bakhtin (1992), que nos permite ler no espaço-mundo o tempo da história.

É na coexistência de saberes que aprendemos sobre o tempo. Passado, presente e futuro. Infância, idade adulta, velhice. São conceitos e configurações que permeiam nossas experiências humanas, entretecidas de instantes, memórias e encontros, construídos e reconstruídos em retornos e rupturas, que quebram os ciclos e desfazem os fios da linha reta. Cada experiência é única, ímpar, solitária e, ao mesmo tempo, coletiva.

Benjamin (1985) alerta-nos que, assim como os acontecimentos históricos não podem ser desfiados como as contas de um rosário, a vida humana não pode ser segmentada como um edifício. Desse modo, a infância, longe de ser uma etapa da vida, representa, alegoricamente, 
o resgate do passado, que ressignifica o presente e o futuro, trazendo à tona a diversidade, o inusitado e sentidos que subvertem o mundo ordenado pelos adultos. Nessa perspectiva, a infância reacende a atitude crítica perante a história ao suscitar a possibilidade de concretizar o que não pôde se realizar porque sufocado ou proibido. Isto se faz notar nos dizeres, nas escritas, nos mapas desenhados, nas ações e nos significados que as crianças tecem quando lhes são abertos espaços e tempos para o diálogo sobre suas vidas na escola. Nessas linguagens, as crianças deixam visível o quanto a sua posição social de infantes, adjetivada por uma suposta inabilidade e desorientação, permite-lhes conferir às experiências, no espaço e no tempo, sentidos outros, destoantes da determinação cultural, revelando ao adulto o que ele não consegue mais ver.

Embora imersos em crises e conflitos que a velocidade das mudanças culturais nos provoca cotidianamente, cabe-nos admitir e reconhecer, no cenário contemporâneo, as singularidades, possibilidades e limites revelados pelos tempos de vida do outro, sobretudo quando esse outro, no caso da criança e do adolescente, está sob a égide dos olhares e das preocupações sociais, na condição de alvo dos investimentos educacionais. Nessa perspectiva, os tempos das novas gerações não podem ser aprisionados por uma agenda que determina o ciclo e a trajetória a serem cumpridos, com vistas a um futuro capturado pelo progresso. Trata-se de salientar a riqueza e a diversidade que as experiências das novas gerações têm nos revelado no tempo presente, que é o tempo dos encontros e confrontos, o tempo do imprevisível, do kairos, que escapa da certeza imposta pela cronologia.

Por ora, não a hora cronológica, mas a hora de um olhar que se volta para o ócio como tempo da aprendizagem e como tempo do agoras, intentamos imprimir, neste ensaio, uma visada do tempo, parafraseando Lloret (1998), em sua condição de amigo e não de cárcere. Amigo que se faz presente e nos interpela nas diferentes temporalidades da vida: na infância, na juventude, na vida adulta e na velhice.

Esse tempo, o qual não se pode mensurar e que os calendários não podem datar nem os números contar, é o tempo do instante, do momento, do agoras e da experiência que nos toca e se liberta das amarras do igual e do sempre eterno. Buscamos dar visibilidade a esse tempo na vida das crianças pelo viés da perspectiva infantil ao percebermos que, nesse devir criança, há sempre rupturas com a temporalidade contínua, progressiva e linear. Essa ideia parte do princípio de que a criança se constitui como um sujeito que transcende ao que está posto e se liberta para o tempo do prazer, em uma fuga permanente da padronização que a sociedade lhe impõe.

Nossas reflexões partem da preocupação com as relações criança-adulto, estabelecidas e pautadas em hierarquias e não em alteridades e diversidades que as atravessam e as constituem; relações estas ainda vigentes e fortemente percebidas em diferentes contextos sociais. Ele-

Educação \& Realidade, Porto Alegre, v. 41, n. 4, p. 1027-1048, out./dez. 2016.1045 
gemos a escola como um desses contextos e nela identificamos que, na maioria das vezes, a postura autoritária dos adultos é a principal marca das relações que são instituídas com as crianças, permeadas pela ideia de que a criança é o ser da falta, aquele que nada sabe e, portanto, nada pode. Sujeito cujo presente apenas ganha sentido como tempo da instrução, o que lhe nega o direito de participação no contexto escolar.

Dessa forma, nestas poucas linhas escritas, procuramos evidenciar a singularidade da infância, como possibilidade de suscitar novas concepções sobre o tempo e, em particular, sobre a potente ruptura que a criança provoca na linearidade e na continuidade do tempo cronológico. Espera-se, com isto, que outras trajetórias e jornadas possam ser vividas nos espaços e tempos das escolas, transformando práticas educativas e modos de conceber e se relacionar com as crianças na contemporaneidade.

Recebido em 06 de dezembro de 2015 Aprovado em 27 de abril de 2016

\section{Notas}

1 Expressão retirada do poema de Manuel Bandeira, em homenagem ao poeta Mario Quintana, os quintanares são os cantares do poeta gaúcho.

2 Como mencionado na primeira parte deste artigo, as referências às crianças são feitas por meio de pseudônimos escolhidos por elas próprias no processo da pesquisa.

\section{Referências}

ANDRADE, Daniela Barros da Silva Freire; TEIBEL, Érica Nayla Harrich. As crianças que existem no aluno e seus discursos sobre a escola. In: ANDRADE, Daniela Barros da Silva Freire; LOPES, Jader Janer Moreira (Org.). Infâncias e Crianças: lugares em diálogos. Cuiabá: EdUFMT, 2012. P. 121-144.

AGAMBEN, Giorgio. Infância e História: destruição da experiência e origem da história. Belo Horizonte: Editora UFMG, 2005.

ARROYO, Miguel González. A Infância interroga a Pedagogia. In: SARMENTO, Manuel Jacinto; GOUVEA, Maria Cristina Soares de (Org.). Estudos da Infância: educação e práticas sociais. Petrópolis: Vozes, 2008. P. 119-140.

ARROYO, Miguel González. Imagens Quebradas: trajetórias e tempos de alunos e mestres. 5. ed. Petrópolis: Vozes, 2009.

BAKHTIN, Mikhail Mikhailovitch. Estética da Criação Verbal. São Paulo: Martins Fontes, 1992.

BENJAMIN, Walter. Obras Escolhidas: magia e técnica, arte e política. 2. ed. v. 1. São Paulo: Brasiliense, 1985.

BUCKINGHAM, David. After the Death of Childhood: growing up in the age of electronic media. Cambridge: Polity Press, 2000.

CASTRO, Lucia Rabello de (Org.). Infância e Adolescência na Cultura do Consumo. Rio de Janeiro: Nau, 1999.

CORSARO, William A. Sociologia da Infância. Porto Alegre: Artmed, 2011.

1046 Educação \& Realidade, Porto Alegre, v. 41, n. 4, p. 1027-1048, out./dez. 2016. 
ELIAS, Norbert. Sobre o Tempo. Rio de Janeiro: Jorge Zahar, 1998.

JOBIM E SOUZA, Solange; CASTRO, Lúcia Rabello de. Pesquisando com crianças: subjetividade infantil, dialogismo e gênero discursivo. In: CRUZ, Sílvia Helena Vieira (Org.). A Criança Fala: a escuta de crianças em pesquisas. São Paulo: Cortez, 2008. P. 52-78.

LAFARGUE, Paul. O Direito à Preguiça. São Paulo: Claridade, 2003.

LLORET, Caterina. As outras idades ou as idades do outro. In: LARROSA, Jorge; LARA, Nuria Perez de (Org.). Imagens do Outro. Petrópolis: Vozes, 1998. P. 13-23.

LOPES, Jader Janer Moreira. As crianças, suas infâncias e suas histórias: mas por onde andam suas geografias? Educação em Foco, Juiz de Fora, v. 13, n. 2, p. 3-44, jan. 2009.

LOPES, Jader Janer Moreira. As crianças e seus espaços vivenciais: caminhos e possibilidades de pesquisas. In: MICARELLO, Hilda; SCHAPPER, Ilka; LOPES. Jader Janer Moreira (Org.). Itinerários Investigativos: infâncias e linguagens. Juiz de Fora: Editora UFJF, 2012. P. 158-166.

MORIYÓN, Félix Garcia. A infância, um território fronteiriço. In: KOHAN, Walter Omar (Org.). Devir-criança da Filosofia: infância da educação. Belo Horizonte: Autêntica Editora, 2010. P. 141-151.

POSTMAN, Neil. O Desaparecimento da Infância. Rio de Janeiro: Graphia, 1999. QUINTANA, Mario. Poesia Completa: em um volume. Organizadora: Tania Franco Carvalhal. Rio de Janeiro: Nova Aguilar, 2005.

SARMENTO, Manuel Jacinto. A reinvenção do ofício de criança e de aluno. Atos de Pesquisa em Educação, Blumenau, PPGE/ME/FURB, v. 6, n. 3, p. 581-602, set./dez. 2011.

VASCONCELLOS, Tânia de. Um minuto de silêncio: ócio, infância e educação. In: LOPES, Jader Janer Moreira; MELLO, Marisol Barenco de (Org.). O Jeito de Que Nós Crianças Pensamos Sobre Certas Coisas: dialogando com lógicas infantis. Rio de Janeiro: Rovelle, 2009. P. 83-95.

VEEN, Wim; VRAKKING, Ben. Homo Zappiens: educando na era digital. Porto Alegre: Artmed, 2009.

Anabela Rute Kohlmann Ferrarini possui mestrado em Educação pelo Programa de Pós-Graduação da Universidade Federal de Mato Grosso, campus de Rondonópolis (2013). Graduada em Pedagogia pelo Centro de Ensino Superior de Rondonópolis (2008), com Especialização em Didática e Metodologia do Ensino Superior pela Anhanguera/Rondonópolis e Especialização em Educação Infantil pela Universidade Federal do Mato Grosso (Campus Rondonópolis). É professora da rede municipal de ensino de Rondonópolis. Membro do Grupo de Estudos Infância, Juventude e Cultura Contemporânea (UFMT/CUR). Atua como supervisora do Pacto Nacional pela Educação em Mato Grosso.

E-mail: anabelaferrarini@hotmail.com

Fabiana Rodrigues Oliveira Queiroz possui graduação em Geografia pela Universidade Federal de Mato Grosso (2008), Mestrado em Educação pela Universidade Federal de Mato Grosso, Rondonópolis. É professora temporária na Faculdade de Educação da Universidade Federal de Goiás, Regional

Educação \& Realidade, Porto Alegre, v. 41, n. 4, p. 1027-1048, out./dez. 2016. 1047 
Goiânia. Tem experiência nas áreas de Geografia e Educação, com ênfase em Geografia da Infância, atuando principalmente nos seguintes temas: infância, espaços vivenciais, mídia e escola.

E-mail: disas.fabiana@gmail.com

Raquel Gonçalves Salgado possui graduação em Psicologia pela Universidade Federal do Rio de Janeiro (1993), mestrado em Educação pela Pontifícia Universidade Católica do Rio de Janeiro (1998) e doutorado em Psicologia (Psicologia Clínica) pela Pontifícia Universidade Católica do Rio de Janeiro (2005). Realizou, também, doutorado sanduíche, durante seis meses, no Centre for the Study of Children, Youth and the Media, do Institute of Education, da Universidade de Londres. É Professora Associada da Universidade Federal de Mato Grosso, no Campus de Rondonópolis, e atua no Programa de Pós-Graduação em Educação (PPGEdu) e no Curso de Psicologia. É Coordenadora do Grupo de Estudos Infância, Juventude e Cultura Contemporânea (UFMT/CUR).

E-mail: ramidan@terra.com.br 